\title{
Valorisation of Fish Bones: Effects of Preservation by Formic Acid on AL-extractable calcium, Phosphorus, Magnesium, and Potassium
}

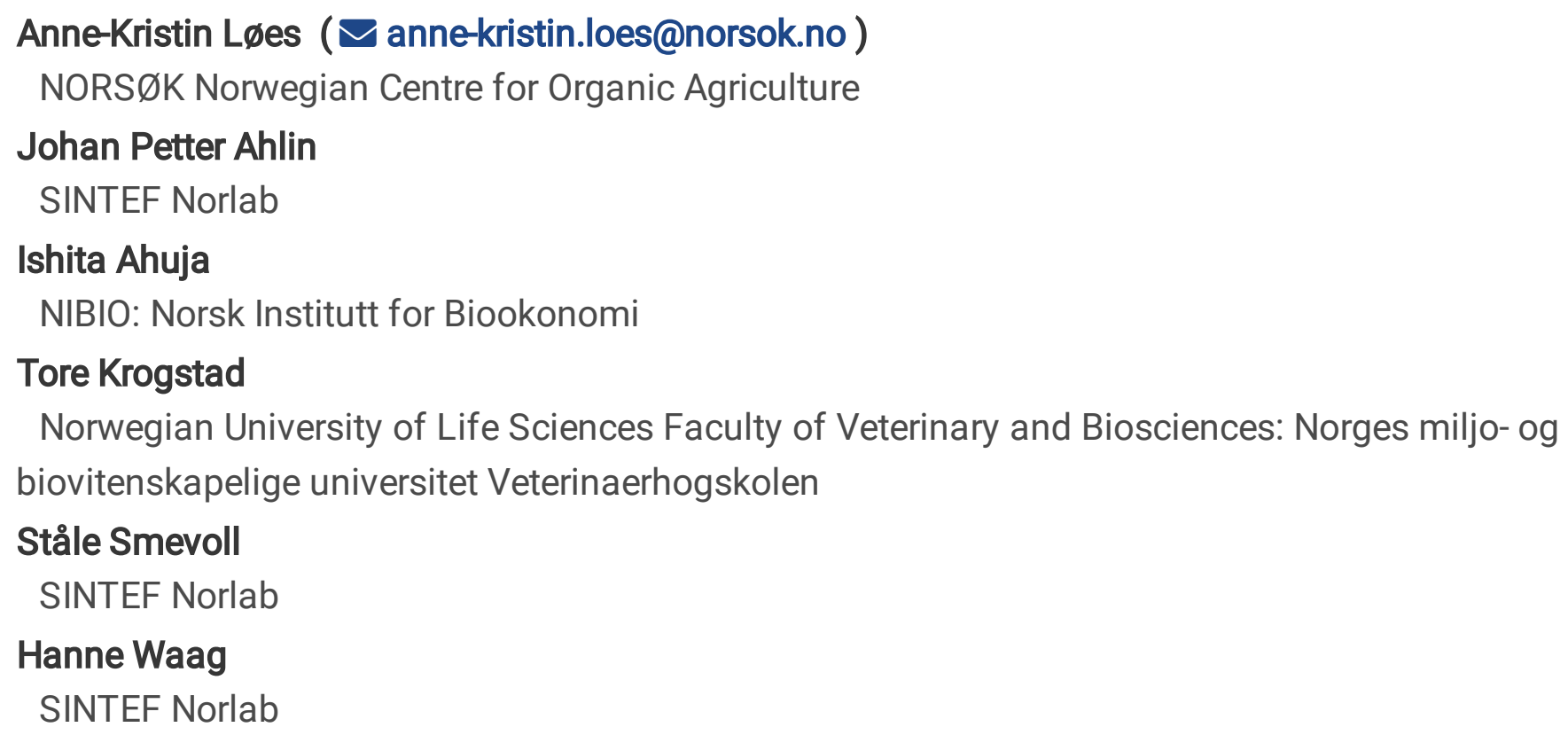

\section{Research Article}

Keywords: Plant nutrients, fertilisation, residual materials, fish industry waste, acidification, grinding Posted Date: November 15th, 2021

DOI: https://doi.org/10.21203/rs.3.rs-1020245/v1

License: (9) This work is licensed under a Creative Commons Attribution 4.0 International License. Read Full License 


\section{Valorisation of fish bones: effects of preservation by formic acid on AL-extractable calcium, phosphorus, magnesium, and potassium}

Authors

A.-K. Løes ${ }^{1)}$, J. P. Ahlin' ${ }^{2)}$, I. Ahuja ${ }^{3)}$, T. Krogstad ${ }^{4)}$, S. Smevoll' ${ }^{5)}$ \& H. Waag ${ }^{5)}$

Affiliations

1) NORS $\varnothing \mathrm{K}$, Norwegian Centre for Organic Agriculture, N-6630 Tingvoll, Norway

2) SINTEF Norlab AS, N-7805 Namsos, Norway

3) Norwegian Institute of Bioeconomy Research (NIBIO), Division of Forest and Forest Resources, Innocamp Steinkjer, N-7713 Steinkjer, Norway

4) Norwegian University of Life Sciences (NMBU), Faculty of Environmental Sciences and Natural Resource Management, N-1430 Ås, Norway

5) SINTEF Norlab AS, N-6650 Surnadal, Norway

\section{Abstract 150-250 words}

Fishbones contain significant amounts of plant nutrients. Fish residues may be preserved by acidification to $\mathrm{pH}<4$, which may affect the extractability and plant availability of nutrients when applied as fertilisers. Grinded bone material from cod (Gadus morhua) heads was mixed with formic acid to investigate if acidification would increase the concentrations of ammonium acetate-lactate $(\mathrm{AL})$-extractable nutrients. Two degrees of fineness of fishbones (coarse $2-4 \mathrm{~mm}$; fine $<0.71 \mathrm{~mm}$ ) were compared at $\mathrm{pH} 3.0$ and 4.0 plus a water control in a laboratory study over 55 days. Samples for extraction of $\mathrm{AL}$-soluble $\mathrm{P}, \mathrm{Ca}, \mathrm{Mg}$ and $\mathrm{K}$ were taken on day 2, 15, 34 and 55 . Whereas acidification clearly increased the concentrations of $A L$-extractable calcium (Ca-AL) and magnesium (Mg-AL), extractable phosphorus ( $P-A L)$ was only significantly increased in finely grinded bones at $\mathrm{pH}$ 3. After 34 days, $6 \%$ of the total content of $\mathrm{P}$ was extracted by $\mathrm{AL}$ in fine fishbones at $\mathrm{pH} 3$. Without acidification about $1 \%$ of the $P$ was extracted, possibly from phospholipids. This P-AL concentration was well above P-AL extracted from acidified coarse fishbones and from fine fishbones acidified to $\mathrm{pH}$ 4. With acidification, about $30 \%$ of total $\mathrm{Ca}$ and $10 \%$ of total $\mathrm{Mg}$ were extracted by $\mathrm{AL}$, and the $\mathrm{Ca}-$ $\mathrm{AL}$ and $\mathrm{Mg}-\mathrm{AL}$ concentrations were closely correlated. The reason for lower $\mathrm{P}-\mathrm{AL}$ in coarse fishbones at $\mathrm{pH} 3$ and 4 , and fine fishbones at $\mathrm{pH} 4$ than in water controls may be a precipitation of apatite from phospholipids and dissolved calcium.

\section{4-6 keywords for indexing}

Plant nutrients, fertilisation, residual materials, fish industry waste, acidification, grinding

Statements and declarations

The authors have no competing interests to declare that are relevant to the content of this article. 


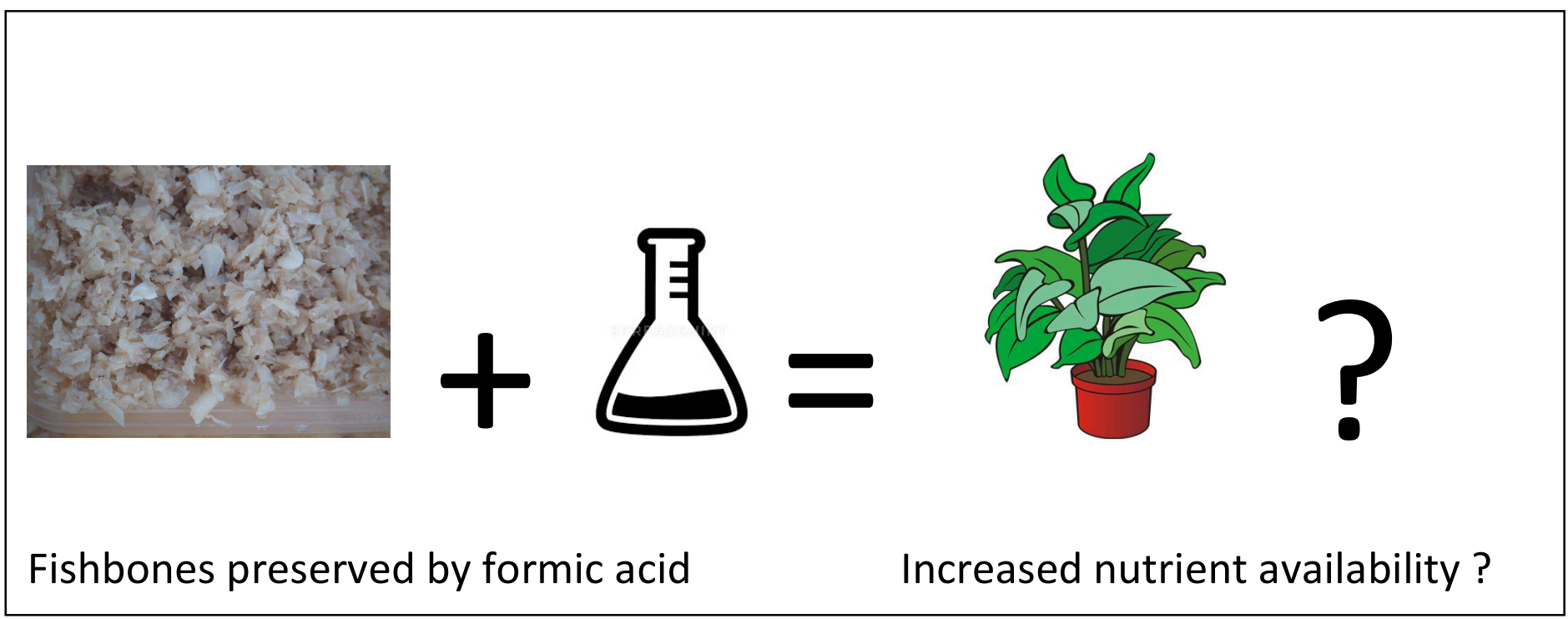

\section{Statement of novelty}

Fish and other sea-living animals have traditionally been applied as fertilisers. In modern fish industry, poorly utilised residual materials with high proportions of fishbone are often available. Such materials may be preserved by acids to below $\mathrm{pH} 4$ to avoid putrefaction. Fishbones contain valuable plant nutrients, such as nitrogen, phosphorus, calcium, and magnesium. Will preservation with formic acid affect the availability of nutrients for crop plants, if acidified fishbones are applied as fertilisers? We measured the concentrations of extractable plant nutrients in acidified fishbones over time, to assess this question. For phosphorus $(\mathrm{P})$, acidification to $\mathrm{pH} 3$ and fine milling of the fishbones was required to increase concentrations of extractable $P$ significantly.

\section{Acknowledgements}

Funding for this study was kindly provided by the County municipality of Møre and Romsdal, Norway for the project "Marine rest raw materials for fertilizers to organic agriculture" (RESTOR, 2017-2021). Introduction

Large amounts of residual materials are produced in fisheries (Ahuja et al 2020), and from lean fish like cod (Gadus morhua) and saithe (Pollachius virens), the utilisation of residual materials is sometimes poor. Residues from whole fish brought to shore and filleted, like heads, backbones, and viscera, may be grinded $(10 \mathrm{~mm})$ and mixed with $85 \%$ formic acid to $\mathrm{pH}<4.0$, to avoid putrefaction. Such material may be stored in large tanks where it will be subject to a hydrolysis, where layers of oils and soluble proteins will form above a layer of sediment. Whereas oil and soluble proteins can be applied for feed in aquaculture, the sediment layer is currently commonly disposed of as waste. Fish bones have a high content of minerals such as nitrogen $(\mathrm{N})$, phosphorus $(\mathrm{P})$ and calcium (Ca) (Toppe et al. 2007) which are essential for the growth of crop plants. Phosphorus is a scarce resource (Cordell \& White 2011), and waste disposal e.g., incineration commonly implies that $P$ is lost from biological circulation. Application of the sediments in agriculture for fertilisation purpose could be a sustainable valorisation of a currently wasted material with valuable characteristics. Pot and field 
experiments have shown that fishbones are an efficient fertiliser for crop plants (Ahuja \& Løes 2019; Løes et al. 2021).

Plants may excrete organic acids from their root systems to extract nutrients from soil (Adeleke et al. 2017), and diluted organic acids are applied as extractants in chemical soil analysis to mimic this effect and measure "plant available" concentrations of essential nutrients in agricultural soil. In Norway and Sweden, the AL-method where a mixture of acetic and lactic acids is applied to extract $\mathrm{P}$, $\mathrm{Ca}$, potassium $(\mathrm{K})$, magnesium $(\mathrm{Mg})$ and sodium $(\mathrm{Na})$ from agricultural soil is the standard method for assessing the need of application of fertilisers to the soil (Egner et al. 1960; Krogstad 1992). Formic acid has been tested and recommended as an appropriate extractant to assess the bioavailability of minerals e.g., in biochars (Wang et al 2012), and extractions with ammonium citrate, $2 \%$ citric acid, and $2 \%$ formic acid are the most common methods to determine the bioavailability of $P$ from rock phosphates (IFA 2013). Since formic acid will solubilise more phosphate from e.g., rock phosphates than water, we may expect that the preservation of grinded fish bones with formic acid may affect the plant availability of $\mathrm{P}$ and $\mathrm{Ca}$, possibly also other nutrients, in this material.

Bone is a composite material composed of organic and inorganic components, primarily collagen and hydroxyapatite $\left(\mathrm{Ca}_{10}\left(\mathrm{PO}_{4}\right)_{6}(\mathrm{OH})_{2}\right.$, also called bioapatite), as well as lipids and water (Szpak 2011). Fishbones tend to exhibit more variability in the chemical composition than bones from mammals, and the collagen from fishbones is also chemically different. In most fish species except skates, sharks and rays, type I collagen is the structural organic element in the bones, being calcified to a variable extent dependent on fish species, type of organ and fish age. In general, for bones collagen constitutes about $20 \%$ of the bone mass and $35 \%$ by volume (Szpak 2011), and collagen comprises more than $90 \%$ of the bone organic matrix. Glycine is the major amino acid comprising about $30 \%$ of the total content of the collagen. The content of hydroxyproline is especially large in collagen and contributes to increase the stability and decrease the solubility of this protein. In the inorganic phase, elements like fluoride and chloride, and mineral carbonate, may also be present in the bioapatite. Lipids and proteins are present in fish bones even after enzymatic hydrolysis or boiling (Malde et al. 2010). In most fish species, the bone structure is acellular (Malde et al. 2010); among the commonly captured or raised species in Norway, only salmonids have cellular bones. Acellular fish bones have smaller crystals and a higher surface to volume ratio than cellular fish bones (Malde et al. 2010), which may affect degradation of such bone particles in soil.

Apatite is relatively insoluble at near-neutral pH (Welch et al 2002). With acidic conditions, such as in fish industry sediments preserved by formic acid, the hydroxyapatite crystals in fish bones will start to dissolve. In aqueous acidic media, the steady-state conditions of apatite dissolution, as reviewed by Dorozhkin (2012) include a series of simultaneous processes or steps: (1) diffusion of chemical reagents (hydrogen ions, $\mathrm{H}^{+}$and anions of acid, $\mathrm{A}^{\mathrm{n}}$ ) from bulk solution to the solid/liquid interface; (2) adsorption of the chemicals onto the surface of apatite; (3) chemical transformations on the surface; (4) desorption of products (ions of calcium, potentially other cations and orthophosphate, $\mathrm{PO}_{4}{ }^{3-}$ ) from the crystal surface; and (5) their diffusion into the bulk solution. If conditions (e.g., $\mathrm{pH}$ ) allow for microbial activity, the organic compounds (collagen, lipids) will attract such activity, which may contribute to dissolution of apatite (Welch et al 2002).

When chemical extraction is applied to estimate the bioavailability e.g., of $\mathrm{P}$ in soil, the ratio of liquid (L) to solid (S) phase is usually wide. The L:S ratio affects the solubility of phosphate. E.g., in a study by Porto et al. (2018), when the amount of $2 \%$ citric acid ( $\mathrm{pH} 2.0$ ) applied per $\mathrm{g}$ of milled rock increased from 100 to $200 \mathrm{ml}$, the concentration of phosphate increased by almost $50 \%$, from 5.5 to $10.7 \mathrm{mg} \mathrm{L}^{-1}$, on average for 10 types of apatite rock. A further increase to $300 \mathrm{ml}$ increased the average concentration to $13.0 \mathrm{mg} \mathrm{L}^{-1}$, demonstrating that the effect of increasing $\mathrm{L}: \mathrm{S}$ ratio levels off. 
A wide $L: S$ ratio, and shaking during extraction, ensures that all material surface is exposed to chemical reactions, and favours diffusion of solubilised ions. When acids are applied for preservation purpose in fish industry, the consumption of acid is minimized to save costs and reduce risks related to health and environmental damage. A narrow $L: S$ ratio may lead to precipitation and re-structuring of the chemical elements e.g., formation of calcium complexes such as calcium formate.

Formic acid is the simplest carboxylic acid, with the formula $\mathrm{HCOOH}$ and a negative log value of acid dissociation constant, pKa being 3.75. This pKa implies that by pH 3.75, 50\% of the molecules will be dissociated to $\mathrm{H}^{+}$and $\mathrm{COOH}^{-}$; at lower $\mathrm{pH}$, a lower proportion will be dissociated. The low molecule weight $\left(21.7 \mathrm{~mol} \mathrm{~kg}^{-1}\right)$ implies that one weight unit of this acid may be a more reactive agent than one weight unit of organic acids with larger molecule weight (Jendza 2017). For comparison, citric acid $\left(\mathrm{CH}_{2} \mathrm{COOH}-\mathrm{C}(\mathrm{OH}) \mathrm{COOH}-\mathrm{CH}_{2} \mathrm{COOOH}\right)$ has a molecule weight of 192.1 and a pKa1 of 3.15. A $85 \%$ formic acid has a $\mathrm{pH}$ of 1.5 .

In the fish industry, there is increasing interest to valorise poorly utilised materials, such as sediments with fish bones. To utilise such materials e.g., in a production of a commercial fertiliser, it is useful to understand how the application of formic acid to $\mathrm{pH}<4$ affects the bioavailability of $\mathrm{P}$ and other essential minerals for plant growth.

As demonstrated by the solubility of rock apatite in citric acid (Porto et al. 2018), we expected that the concentration of AL-extractable $P$ in fishbones treated with formic acid would be higher than in fishbones not treated by acid. We also expected that the fineness of grinding, and decrease in $\mathrm{pH}$, would increase the concentration of AL-extractable $\mathrm{P}$ in the fishbones. These assumptions were tested in a laboratory scale study which is presented here. The purpose of the present study was to assess the effect of mixing grinded fish bones with formic acid on the concentration of AL-extractable $P$ and other elements which are important for the growth of crop plants and commonly assessed in the same extract (potassium, $\mathrm{K}$; calcium, Ca; magnesium, Mg). The study was initiated by a measurement of volumes of formic acid required for targeted $\mathrm{pH}$ levels in slurries of fishbones and deionised water, whereas the main part was to assess how the amendment of fishbones with targeted amounts of formic acid affected the concentrations of AL-extractable elements.

Materials and methods

Fishbones to be applied in the present study were provided by SINTEF Ocean AS as an output from the project "Heads up I", aiming at a better utilization of cod heads than drying them for export. Cod heads were subject to enzymatic hydrolysis in a pilot plant (Remme et al. 2018). The remaining sediments were thoroughly washed to derive to a material containing only bone particles, and then frozen and stored at $-18^{\circ} \mathrm{C}$. The frozen bones were dried at $40^{\circ} \mathrm{C}$ and grinded with a kitchen blender. The grinded material was sieved to produce a coarse fraction with particle diameter 2-4 mm, further called coarse fishbones (CFB) and a fine fraction passing a $0.71 \mathrm{~mm}$ sieve, further called fine fishbones (FFB). The volume of formic acid required for achieving a certain $\mathrm{pH}$ value in CFB and FFB was assessed in an initial buffering capacity test. Thereafter, the main experiment was conducted over a period of 55 days, where a slurry of fishbones and concentrated formic acid was regularly sampled and the samples subject to extraction by ammonium-acetate lactate (AL) solution. The ALmethod (Egner et al. 1960) is the standard method in Norway to assess the plant availability of $P, K$, $\mathrm{Ca}, \mathrm{Mg}$ and $\mathrm{Na}$ (Krogstad 1992). Dried samples of material are extracted by a mixture of $0.1 \mathrm{M}$ ammonium lactate and $0.4 \mathrm{M}$ acetic acid, $\mathrm{pH} 3.75$, and the concentrations of phosphate and other ions in the extract are measured after filtration by Inductive Coupled Plasma mass spectroscopy (ICP$\mathrm{MS}) . \mathrm{pH}$ in the slurries were measured at each sampling date. 
The chemical characteristics of applied fishbones was assessed at SINTEF Norlab department Namsos (Table 1). One sample of CFB and one of FFB were analysed for $\mathrm{pH}$, concentration of total carbon (C) and nitrogen $(\mathrm{N})$, nitrate, ammonium and 22 mineral elements. $\mathrm{pH}$ was measured after application of deionised water ( $v: v 1: 2.5$ ). For total $\mathrm{C}$, thermal decomposition at $1200-1500{ }^{\circ} \mathrm{C}$ to convert all carbon into $\mathrm{CO}_{2}$ was applied in a total organic carbon analyzer, including a step to measure $\mathrm{CO}_{2}$ by a detector, following NS-EN 15936: 2012. For total N, Kjeldahl-N was applied, where all nitrogen is converted to ammonium sulphate by application of concentrated sulfuric acid, converting ammonium to ammonia gas by application of sodium hydroxide and measuring the amount of ammonia by distillation into hydrochloric acid and measuring the amount of acid not reacting with ammonia. For determination of ammonium, the ammonium concentration was determined by a photometer after developing a blue coloured complex with thymol, following an internal method for extraction and NS-EN ISO 11732. For determination of nitrate and chlorine, the sample was extracted with deionised water for one hour, and concentrations measured by ionic chromatography. For iodine, nitric acid and alkalic stabilisation was applied for dissolution before measurement by ICP-SFMS/ICP-AES.

Multi-element determination of selected elements by ICP-MS (internal method based on NS-EN ISO 17294-2: 2016) consists of a chemical digestion of the sample (fishbones or AL-extracts) by a nitric acid/hydrogen peroxide solution at $120^{\circ} \mathrm{C}$ for 30 minutes to bring ions into aquatic solution, followed by a quantitative assessment of concentrations of elements by the measuring instrument, Agilent ICP-MS 7900.

Volumes of formic acid required for targeted $\mathrm{pH}$ levels in fishbones

The main experiment, to measure AL-extractable elements in fishbones treated with various concentrations of formic acid, was planned to comprise one treatment of $\mathrm{pH} 5.0$, one treatment of $\mathrm{pH}$ 3.0, and a control with only de-ionised water. To assess the amount of acid required to achieve these pH levels, aliquots of $25 \mathrm{~g}$ material (CFB, FFB) were placed in $500 \mathrm{ml}$ plastic flasks, and $100 \mathrm{ml}$ of deionised water applied to each flask. Thereafter, diluted formic acid (FA) was added to the flasks, while measuring over a period of 59 days the amounts of FA which were required to derive a pH of about 5.0 and 3.0. The dilution was one part of concentrated FA (98-100 \%) to nine parts of deionised water. The required amounts of diluted acid are shown in Table 3. A control treatment comprised application of deionised water only, and $\mathrm{pH}$ values over time are shown in Table 2. For the control treatment we had one replicate of each material, whereas for the treatments with FA we had three replicates per treatment. In total this test comprised 14 flasks over 6 treatments. The $\mathrm{pH}$ in the control flasks were measured on Day 1, 11, 21, 26 and 50 after mixing water and fishbones in the flasks (Table 2), whereas in acidified flasks pH was measured on Day $0,1,3,7,14,30$ and 59 (Table 3), before application of $10 \%$ FA. Thereafter, the volume of diluted FA required to achieve a stable pH of 5.0 or 3.0 was measured. Between the $\mathrm{pH}$ measurements, the flasks were kept closed by screw caps. Before each $\mathrm{pH}$ measurement, the flasks were thoroughly shaken. The $\mathrm{pH}$ values were measured directly in the flasks. 
The test revealed that a stable $\mathrm{pH}$ of 5.0 would be very challenging to achieve. Hence, we decided that the main experiment should target $\mathrm{pH}$ levels of approximately $\mathrm{pH} 3.0$ and 4.0. The test revealed that slightly more FA, $7.04 \mathrm{ml}$ per $\mathrm{g}$ of fishbones was required for FFB to achieve a stable value of $\mathrm{pH}$ 3.0, as compared with $6 \mathrm{ml}$ for CFB.

To decide the amounts of $85 \%$ acid required for achieving stable $\mathrm{pH}$ values of 3.0 and 4.0 , batches of $2.5 \mathrm{~g}$ FFB were mixed with $10 \mathrm{ml}$ of deionised water and increasing amounts of 85\% FA from 0.08 to 1 $\mathrm{ml}$ per $\mathrm{g}$ of FFB. After 3 days, the $\mathrm{pH}$ ranged from 4.2 to 2.6. After some further testing, also adjusting the liquid to solid ratio, we found that $1.5 \mathrm{ml}$ of deionised water per $\mathrm{g}$ of fishbones was applicable to achieve a slurry mimicking industrial conditions, and that $0.18 \mathrm{ml}$ of $85 \%$ FA per g of FFB was required for $\mathrm{pH}$ 4.0. For $\mathrm{CFB}$, amounts ranging from 0.1 to $0.16 \mathrm{ml}$ per g were tested, giving $\mathrm{pH}$ values from 4.0 to 3.7 after 3 days. Since we expected that the buffering in CFB would occur over a longer period than for FFB, we chose to apply $0.14 \mathrm{ml}$ of $85 \%$ FA per $\mathrm{g}$ of CFB. To achieve pH 3, we decided to apply 0.38 $\mathrm{ml} 85 \% \mathrm{FA}$ per $\mathrm{g}$ of CFB, and $0.46 \mathrm{ml}$ per $\mathrm{g}$ of FFB. Hence, the ratio of application of FA at $\mathrm{pH} 3 \mathrm{vs} \mathrm{pH} 4$ was $0.38: 0.14=2.7$ for $\mathrm{CFB}$, and $0.46: 0.18=2.6$ for FFB.

\section{Extractable elements in fishbones amended with formic acid}

In the main experiment, we aimed for deriving a sludge of fish bones without a large proportion of visible water, to mimic industry conditions and to facilitate a reasonably uniform sampling of sediments. As described in the previous section, $1.5 \mathrm{~g}$ of deionised water per $\mathrm{g}$ of fishbones was satisfactory for this purpose. Again, $500 \mathrm{ml}$ plastic flasks were applied, $40 \mathrm{~g}$ dry fishbones $+60 \mathrm{ml}$ deionised water were applied to each plastic flask, and thereafter $85 \%$ FA was applied in a volume of 7.2 or $18.4 \mathrm{ml}$ to FFB, and a volume of 5.6 or $15.2 \mathrm{ml}$ to CFB, to achieve a pH of 4.0 or 3.0 . Thereafter the bottles were well shaken and kept closed in room temperature. For control treatments, only deionised water was applied. The six treatments had three replicate flasks, in total 18 flasks. The treatments are abbreviated here as FFB3 (fine fishbones, $\mathrm{pH}$ 3.0), FFB4 (fine fishbones, pH 4.0), $\mathrm{FFBH}_{2} \mathrm{O}$ (fine fishbones, deionised water) and CFB3, CFB4 and $\mathrm{CFBH}_{2} \mathrm{O}$ (coarse fishbones with pH 3, 4 or mixed with deionised water). The experiment lasted from October 6 (day 0 ) to November 30, 2020 (day 55). Sampling occurred on day 2 (Oct 8), 15 (Oct 21), 34 (Nov 9) and 55. On each sampling date, about $13 \mathrm{~g}$ of material was removed from each flask with a plastic spoon, giving a total of $18 \times 4=72$ samples for chemical analysis. On each sampling date, $\mathrm{pH}$ was measured in the flasks before removing the samples, after stirring the slurry with a plastic rod.

The samples were split in two aliquots, where one was used for determination of dry matter content, and the other was extracted by AL-solution as described above. All laboratory work including $\mathrm{pH}$ measurements was carried out at SINTEF Norlab department Surnadal, Norway, whereas other chemical analyses were conducted at SINTEF Norlab department Namsos. Filtrated extracts were kept frozen until determination of the concentrations of $\mathrm{P}, \mathrm{K}, \mathrm{Ca}$, and $\mathrm{Mg}$ by ICP-MS measurement as described above. One sample of frozen extract, from treatment $\mathrm{FFBH}_{2} \mathrm{O}$ was broken on the way to the laboratory, leaving only two replicate samples for analysis of this treatment. 


\section{Statistical analysis}

To test whether changes in characteristics between sampling dates for single treatments were statistically significant, we applied a paired t-test. To compare if the average characteristic on a certain date differed significantly between only two treatments, we applied a two-sample t-test. To compare if the average values were statistically significant between treatments on each sampling date, we applied one-way analysis of variance (GLM) with a Tukey t-test to analyse differences between means. The calculations were made by Minitab software.

Statistically significant differences are referred to as $* * *$ for $p<0.001, * *$ for $p<0.01, *$ for $p<0.05$ and nearly significant as $\left({ }^{*}\right)$ for $0.05<p<0.1$. 
Results

Chemical characteristics of applied fish bones

Table 1 Chemical characteristics of fishbones applied in the study. DM = dry matter

Characteristic

Dry matter

$\mathrm{pH}$

Total organic $\mathrm{C}$

Total N

Nitrate

Ammonium

Phosphorus (P)

Calcium (Ca)

Magnesium (Mg)

Potassium (K)

Sulphur (S)

Chloride (Cl)

lodine (I)

Boron (B)

Cobalt (Co)

Iron (Fe)

Manganese (Mn)

Molybdenum (Mo)

Arsenic (As)

Cadmium (Cd)

Chromium (Cr)

Copper (Cu)

Lead $(\mathrm{Pb})$

Mercury (Hg)

Nickel (Ni)

Zink (Zn)

Silver (Ag)

Tin (Sn)

\section{Unit of measurement}

$\%$

\% of DM

$\%$ of DM

$\mathrm{mg} \mathrm{N} \mathrm{kg} \mathrm{DM}{ }^{-1}$

$\mathrm{mg} \mathrm{N} \mathrm{kg} \mathrm{DM}^{-1}$

$\%$ of DM

$\%$ of DM

$\%$ of DM

$\%$ of DM

$\%$ of DM

$\mathrm{mg} \mathrm{kg} \mathrm{DM}^{-1}$

$\mathrm{mg} \mathrm{kg} \mathrm{DM}^{-1}$

$\mathrm{mg} \mathrm{kg} \mathrm{DM}^{-1}$

$\mathrm{mg} \mathrm{kg} \mathrm{DM}^{-1}$

$\mathrm{mg} \mathrm{kg} \mathrm{DM}^{-1}$

$\mathrm{mg} \mathrm{kg} \mathrm{DM}^{-1}$

$\mathrm{mg} \mathrm{kg} \mathrm{DM}^{-1}$

$\mathrm{mg} \mathrm{kg} \mathrm{DM}^{-1}$

$\mathrm{mg} \mathrm{kg} \mathrm{DM}{ }^{-1}$

mg kg DM ${ }^{-1}$

$\mathrm{mg} \mathrm{kg} \mathrm{DM^{-1 }}$

$\mathrm{mg} \mathrm{kg} \mathrm{DM}^{-1}$

$\mu \mathrm{g} \mathrm{kg} \mathrm{DM}{ }^{-1}$

$\mathrm{mg} \mathrm{kg} \mathrm{DM}^{-1}$

mg kg DM ${ }^{-1}$

mg kg DM ${ }^{-1}$

$\mathrm{mg} \mathrm{kg} \mathrm{DM}{ }^{-1}$

$\begin{array}{ll}\text { Coarse fishbones } & \text { Fine fishbones } \\ \mathbf{2}-\mathbf{4} \mathbf{~ m m} & <\mathbf{0 . 7 1} \mathbf{m m} \\ 92 & 92\end{array}$

$\begin{array}{ll}7.8 & 7.6\end{array}$

$14 \quad 13$

$4.8 \quad 5.2$

$<1.2 \quad 2.0$

$36 \quad 50$

$12 \quad 11$

$30>30$

$0.41 \quad 0.57$

$0.075 \quad 0.062$

$0.18 \quad 0.18$

$130 \quad 150$

$<0.5<0.5$

$580 \quad 410$

$0.060 \quad 0.041$

$<3.8<3.8$

$13 \quad 19$

$<0.17<0.17$

$<0.37<0.37$

$<0.0014 \quad 0.038$

$<0.28 \quad 1.1$

$<0.52<0.52$

$0.19 \quad 0.20$

$2.0 \quad 6.0$

$<0.080 \quad 1.1$

$78 \quad 190$

$<0.085<0.085$

$<3.8 \quad<3.8$

The chemical composition of fishbones was comparable in CFB and FFB. The $\mathrm{pH}$ was slightly alkalic (Table 1). A significant content of carbon and nitrogen indicates that the bones contain a high amount of structural protein (collagen). Among the six macronutrients required for satisfactory growth of crop plants, the fishbones had high concentrations of $\mathrm{N}, \mathrm{P}, \mathrm{Ca}$, and some $\mathrm{Mg}$ and $\mathrm{S}$. The concentration of $\mathrm{K}$ was quite low as compared with the needs of crop plants, who often have $\mathrm{K}$ contents comparable to $\mathrm{N}$. For several elements, the concentration was below the limit of detection.

In a typical apatite, the ratio of molecular weight between $P$ and Ca equals $(6 * 30.97: 10 * 40.08)=0.46$. In the materials studied here, the P:Ca ratio was 0.38 (Table 1 ). This indicates that in addition to apatite, 
some carbonate $\left(\mathrm{CaCO}_{3}, \mathrm{MgCO}_{3}\right)$ is also present. If all $\mathrm{P}$ is present as apatite, it will take up $248 \mathrm{~g}$ of $\mathrm{Ca}$ per $\mathrm{kg}$ of fishbones containing on average $115 \mathrm{~g}$ P per $\mathrm{kg}$ (Table 1). The remaining about $50 \mathrm{~g}$ of Ca per $\mathrm{kg}$ may be present as carbonate. This represents about $6 \%$ of the total calcium content.

\section{Change of $\mathrm{pH}$ over time}

In the control treatments, the $\mathrm{pH}$ in FFB was initially slightly below the $\mathrm{pH}$ of CFB (Table 2). In both types of material, the $\mathrm{pH}$ increased over time, and after about 3 weeks the $\mathrm{pH}$ was somewhat higher in CFB than FFB. Overall, the pH increased from about 7.4 to about 8.5.

In treatments targeted towards $\mathrm{pH} 5.0$, an average total volume of $20 \mathrm{ml} 85 \%$ FA was applied to FFB over 59 days, and $14 \mathrm{ml}$ to CFB, but the $\mathrm{pH}$ was still not stable. For CFB, microbial activity was observed after 7 days, when samples had developed a bad odour and brown-yellowish colour. For FFB, the same was observed after 14 days. The bad odour occurred until the end of the test. When the target $\mathrm{pH}$ was 3.0, it was easier to achieve a stable $\mathrm{pH}$, but this demanded a significant amount of acid (Table 3); 6-7 $\mathrm{g}$ of FA per $\mathrm{g}$ of bones. The acid consumption was higher for FFB where totally $176 \mathrm{ml}$ of FA was required, than for CFB where $150 \mathrm{ml}$ were required. For FFB a stable $\mathrm{pH}$ was achieved already after day 1 , whereas for CFB this was not achieved until after day 14. In the samples targeted towards $\mathrm{pH}$ 3.0, no observations of bad smell or brown-yellowish colour occurred. The colour of these samples was light grey to yellow.

Table $2 \mathrm{pH}$ over time in course fishbones (CFB2, 2-4 mm) and fine fishbones (FFBs, $<0.71 \mathrm{~mm}$ ) mixed with $4 \mathrm{ml}$ of deionised water per $\mathrm{g}$ of fishbones

$\begin{array}{lllllll}\text { Treatment } & \text { Day 0 } & \text { Day 1 } & \text { Day 11 } & \text { Day 21 } & \text { Day 26 } & \text { Day } 50 \\ \text { CFB } & 7.5 & 7.3 & 7.1 & 8.0 & 8.0 & 8.3 \\ \text { FFB } & 7.3 & 7.1 & 7.2 & 8.4 & 8.5 & 8.7\end{array}$

Table $3 \mathrm{pH}$ over time in course and fine fishbones (CFB 2-4 mm, FFB $<0.71 \mathrm{~mm}$ ) mixed with deionised water ( $4 \mathrm{ml}$ per $\mathrm{g}$ of fishbones) plus $85 \%$ formic acid (FA) to derive a target $\mathrm{pH}$ of 5.0 or 3.0

\begin{tabular}{|c|c|c|c|c|c|c|c|}
\hline $\begin{array}{l}\text { Characteristic, treatment } \\
p H\end{array}$ & Day 0 & Day 1 & Day 3 & Day 7 & Day 14 & Day 30 & Day 5 \\
\hline CFB target pH 5.0 & - & 6.3 & - & 6.8 & 7.0 & 7.2 & 7.7 \\
\hline FFB target $\mathrm{pH} 5.0$ & - & 5.4 & 5.2 & 5.5 & 5.6 & 5.6 & 7.0 \\
\hline \multicolumn{8}{|l|}{ mI FA per experimental unit } \\
\hline CFB target $\mathrm{pH} 5.0$ & 0.6 & 0.1 & - & 2.2 & 2.5 & 3.8 & 4.7 \\
\hline FFB target $\mathrm{pH} 5.0$ & 3.2 & 0.7 & 0.2 & 0.8 & 7.3 & 1.4 & 6.7 \\
\hline \multicolumn{8}{|l|}{$\mathrm{pH}$} \\
\hline CFB target $\mathrm{pH} 3.0$ & - & 3.5 & - & 3.4 & 3.1 & 3.0 & 3.0 \\
\hline FFB target $\mathrm{pH} 3.0$ & - & 3.1 & 3.0 & 3.0 & 3.0 & 3.0 & 3.0 \\
\hline \multicolumn{8}{|l|}{ ml FA per experimental unit } \\
\hline CFB target $\mathrm{pH} 3.0$ & 41 & 36 & - & 58 & 15 & 0 & 0 \\
\hline
\end{tabular}


The slurries for the main experiment had less water ( $1.5 \mathrm{~g}$ per $\mathrm{g}$ of fishbones as compared with 4 in the initial test). With applied volumes of $85 \% \mathrm{FA}$, the $\mathrm{pH}$ was quite stable after acidification. The final $\mathrm{pH}$ after 55 days was 2.93 for FFB3, 3.97 for FFB4, 3.20 for CFB3 and 4.00 in CFB4. In control treatments, $\mathrm{pH}$ decreased slightly from 6.7 on day 2 to 6.5 on day 15 for $\mathrm{FFBH}_{2} \mathrm{O}$, then increased to a final pH of 7.9 on day 55. For $\mathrm{CFBH}_{2} \mathrm{O}, \mathrm{pH}$ was 6.9 on day 2 and increased to $\mathrm{pH} 8.0$ on day 55 .

\section{Content of dry matter in the fishbone slurries}

The average content of dry matter (DM) on each sampling date varied from 35 to $54 \%$ (Figure 1). In the control treatments the values were slightly decreasing over time, from 40 to $37 \%$ in CFB and 39 to $35 \%$ in FFB. The decrease from day 2 to 55 in the control treatments was nearly statistically significant $(p=0.053)$ for $\mathrm{FFBH}_{2} \mathrm{O}$, but not for $\mathrm{CFBH}_{2} \mathrm{O}(\mathrm{p}=0.16)$. A decreasing trend may be explained by decomposition of organic material by microbial activity, converting solid material to liquids and gas.

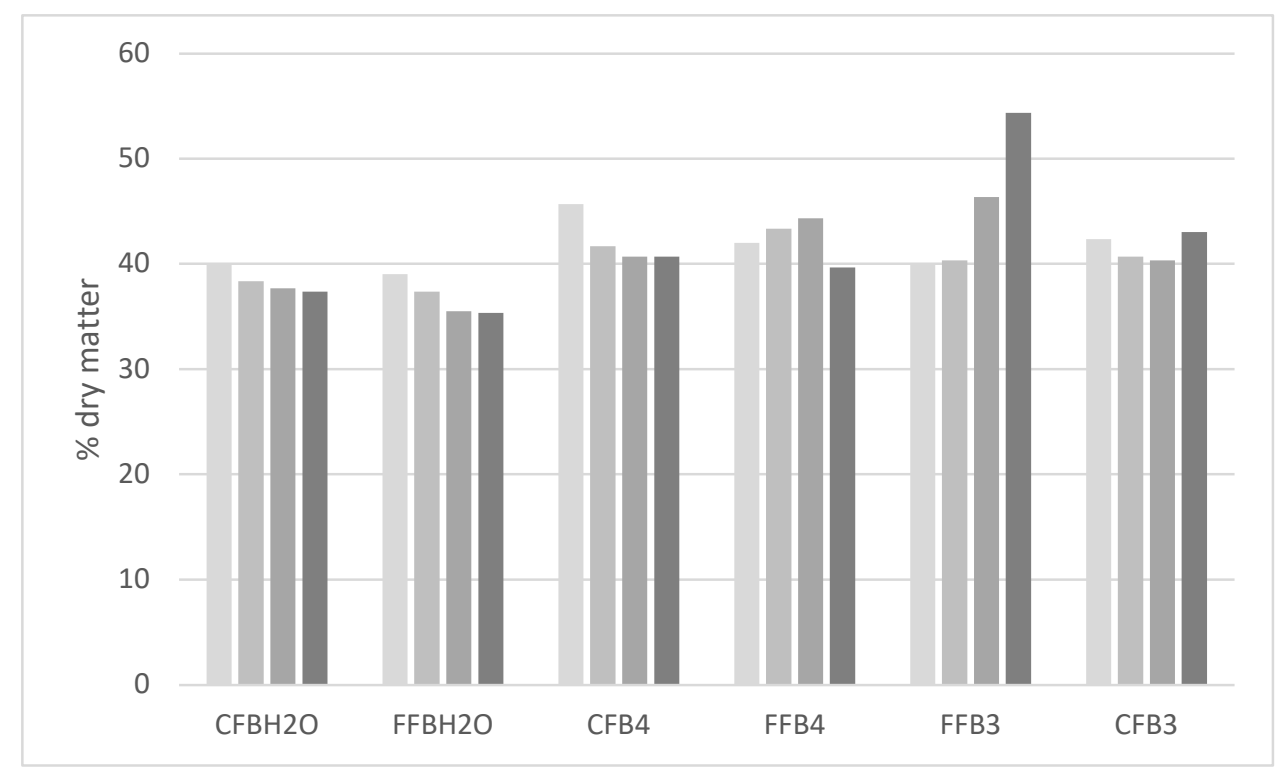

Figure 1 Dry matter (\%) at days 2, 15, 34 and 55 after acidification of grinded fishbones with $85 \%$ formic acid to $\mathrm{pH} 3$ or 4 . Values are averages of 3 replicate samples per treatment. CFB= coarse fishbones $(2-4 \mathrm{~mm}), \mathrm{FFB}=$ fine fishbones $(<0.71 \mathrm{~mm}), \mathrm{H} 2 \mathrm{O}=$ control with only water, numbers 3 and 4 refers to $\mathrm{pH}$

Since formic acid will decompose into carbon monoxide or carbon dioxide plus water vapour by drying at $105^{\circ} \mathrm{C}$, the addition of formic acid was not supposed to increase the dry matter content. However, if chemical reactions occur, e.g., formation of calcium formate, less acid may disappear during drying. The average values were quite stable between 40 and $46 \%$ in CFB3, CFB4 and FFB4 (Figure 1). In FFB3, the content of dry matter seemed to increase over time, especially from day 15 to 34 , and from day 34 to 55 . However, the differences were not statistically significant from one sampling day to the next, or from day 2 to $55(p=0.125)$.

\section{Extractable calcium in fishbones treated with $85 \%$ formic acid}


The dissolution of calcium was significant with application of formic acid and increased with increased acidification for both types of material (Figure 2b). The average concentrations of extractable $\mathrm{Ca}$ (Ca-

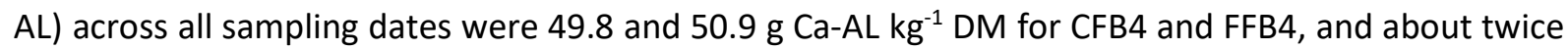

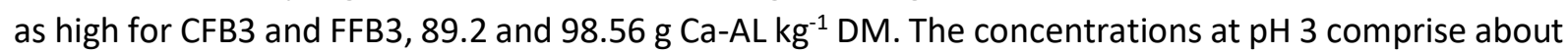
$30 \%$ of the total content of calcium, which was about $300 \mathrm{~g} \mathrm{Ca} \mathrm{kg}^{-1} \mathrm{DM}$ (Table 1).

In the control treatments (Figure 2a) the difference between FFB and CFB was higher than for the acidified treatments; the average concentrations across sampling dates were 548 and $261 \mathrm{mg} \mathrm{Ca}-\mathrm{AL}$ $\mathrm{kg}^{-1} \mathrm{DM}$. The changes from one sampling date to the next, or from the start to the end of the experiment, were not statistically significant for the control treatments. The average values of $\mathrm{Ca}-\mathrm{AL}$ comprised $0.18 \%$ of the total $\mathrm{Ca}$ content for $\mathrm{FFBH}_{2} \mathrm{O}$ and $0.09 \%$ for $\mathrm{CFBH}_{2} \mathrm{O}$. In acidified treatments, several increases in Ca-AL were near to, or statistically significant (Figure 2b).

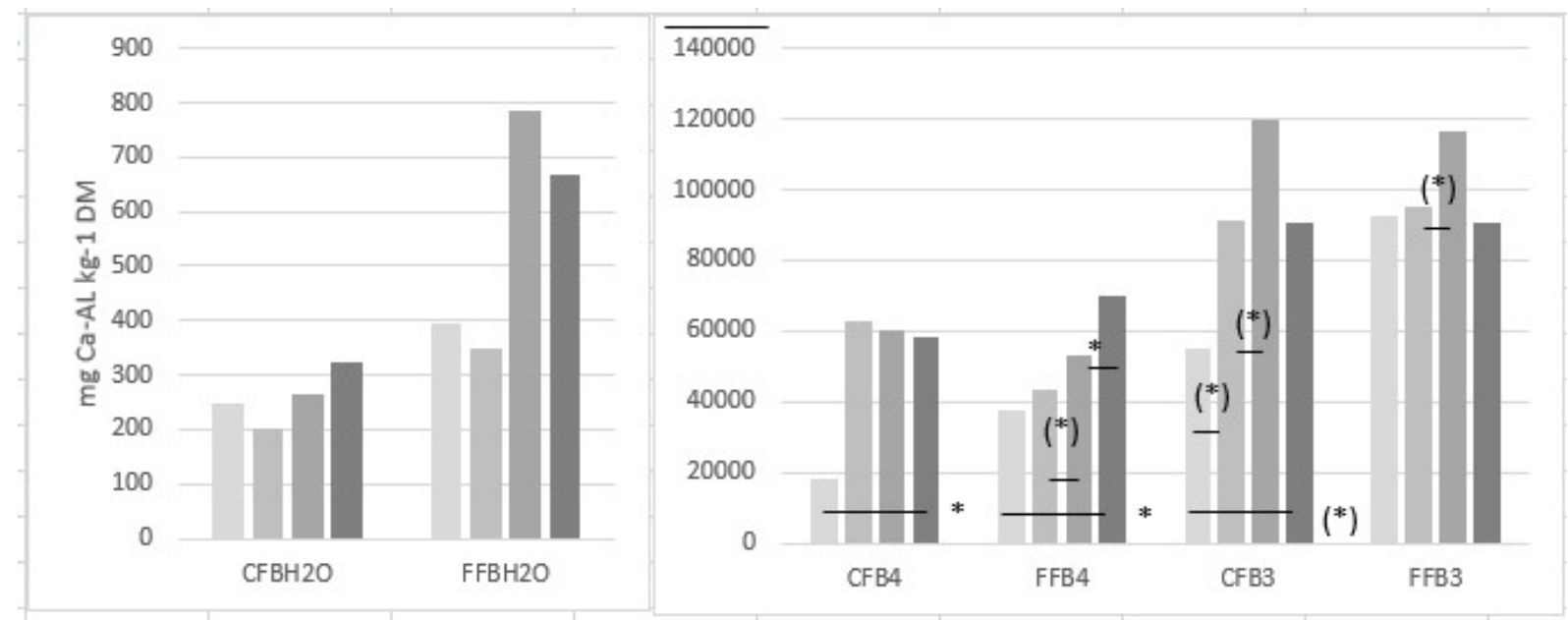

Figure 2 AL-extractable calcium (Ca-AL) at days 2, 15, 34 and 55 after acidification of grinded fishbones with $85 \%$ formic acid to $\mathrm{pH} 3$ or 4 . Values are averages of 3 replicate samples per treatment; sampling days are indicated by increasingly grey colour. CFB= coarse fishbones $(2-4 \mathrm{~mm})$, $\mathrm{FFB}=$ fine fishbones $(<0.71 \mathrm{~mm}), \mathrm{H} 2 \mathrm{O}=$ control with only water, numbers 3 and 4 refer to $\mathrm{pH}$. Left side (2a): control treatments, right side (2b): acidified treatments. Statistically significant changes between sampling dates are indicated by horizontal bars between dates and the level of significance by asterix

The decreases from day 34 to day 55 for CFB3 and FFB3 could possibly indicate that some Ca was chemically bound over time e.g., by formation of complexes such as calcium formate. However, these changes were not statistically significant ( $p=0.206$ for FFB3; $p=0.168$ for CFB3).

For Ca-AL, the effect of grinding was not significant. After 55 days, the concentration of AL-extractable Ca differed significantly between the acidified treatments ( $p=0.000$; GLM), with CFB4 (5.8 g) being lower than CFB3, FFB3 and FFB4 $(9.1,9.0$ and $7.0 \mathrm{~g})$. When FFB and CFB were compared across $\mathrm{pH}$ levels in a two-sample t-test, FFB had significantly more Ca-AL than CFB $(p=0.041)$.

Extractable magnesium in fishbones treated with 85\% formic acid

For extractable $\mathrm{Mg}(\mathrm{Mg}-\mathrm{AL})$, the pattern was quite similar to the pattern of variation in extractable $\mathrm{Ca}$ (Figure 3, Figure 4), and there was a close correlation between these two characteristics $(p=0.000$; $r^{2}=0.8$ ). In the control treatments, concentrations increased from 62 to $128 \mathrm{mg} \mathrm{Mg-AL} \mathrm{kg}{ }^{-1} \mathrm{DM}$ for CFB and from 71 to 253 for FFB. The concentrations were slightly higher for finely ground fishbones (Figure 
4), but the difference in Mg-AL between FFB and CFB amended with water was not statistically valid on any sampling date (Table 4).

In acidified treatments, the concentrations of AL-extractable Mg were much higher (Figure 3). The average total concentration of $\mathrm{Mg}$ in the fishbones was $49 \mathrm{~g} \mathrm{Mg} \mathrm{kg}^{-1}$ of DM (Table 1). The average

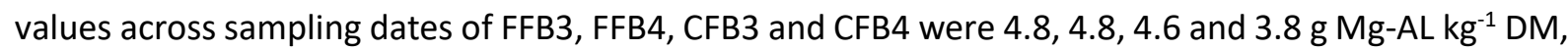
indicating that about $10 \%$ of the total $\mathrm{Mg}$ was solubilised by formic acid treatment. With $\mathrm{pH} 4$, the concentration increased over time in both CFB and FFB. With $\mathrm{pH} 3$, the dissolution of $\mathrm{Mg}$ seemed to occur immediately in FFB and within day 15 in CFB. On each sampling date there was a significant difference between acidified and non-acidified treatments. Comparable to the results for $\mathrm{Ca}-\mathrm{AL}$, no clear effect was found of grinding on the concentration of AL-extractable Mg (Table 4), and the effect of $\mathrm{pH}$ level was also not clear, even if acidification as such increased Mg-AL significantly.

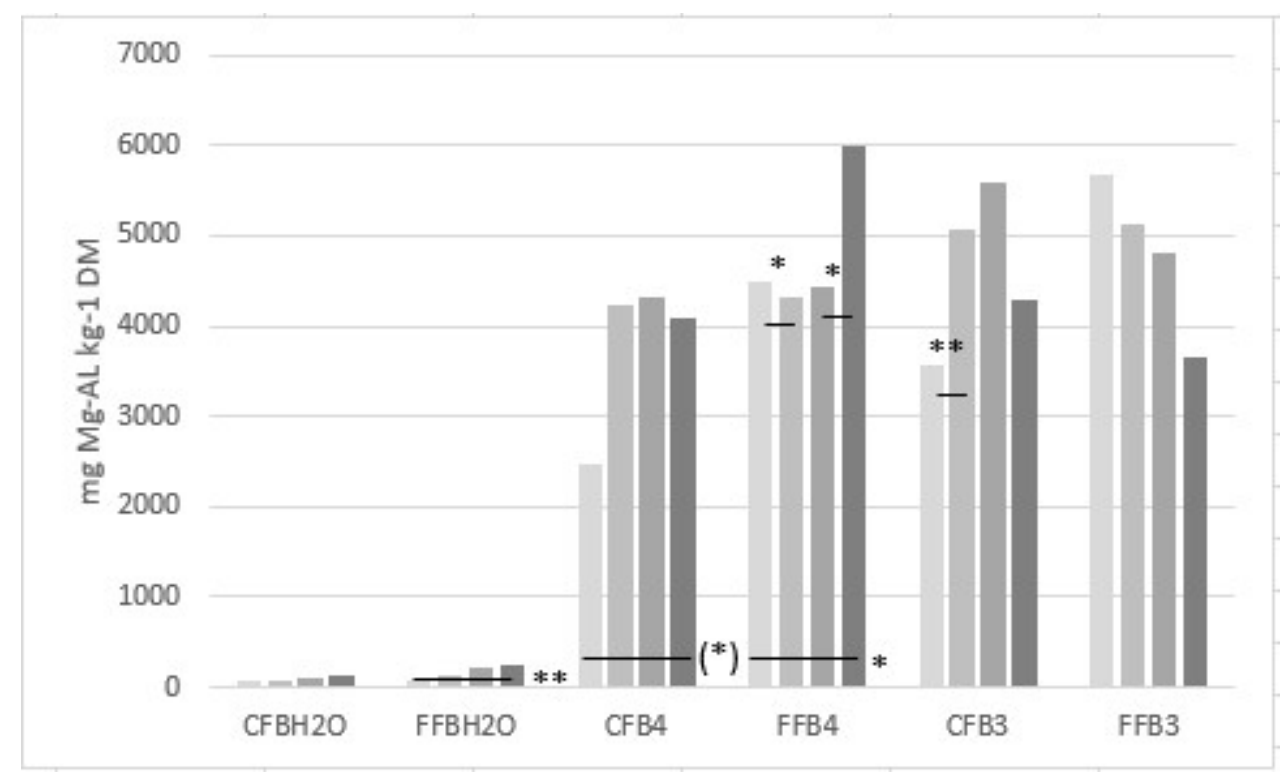

Figure 3 AL-extractable magnesium (Mg-AL) at days 2, 15, 34 and 55 after acidification of grinded fishbones with $85 \%$ formic acid to $\mathrm{pH} 3$ or 4 . Values are averages of 3 replicate samples per treatment; sampling days are indicated by increasingly grey colour. CFB= coarse fishbones $(2-4 \mathrm{~mm})$, $\mathrm{FFB}=$ fine fishbones $(<0.71 \mathrm{~mm}), \mathrm{H} 2 \mathrm{O}=$ control with only water, numbers 3 and 4 refer to $\mathrm{pH}$. Statistically significant changes between sampling dates are indicated by horizontal bars between dates and the level of significance by asterix 


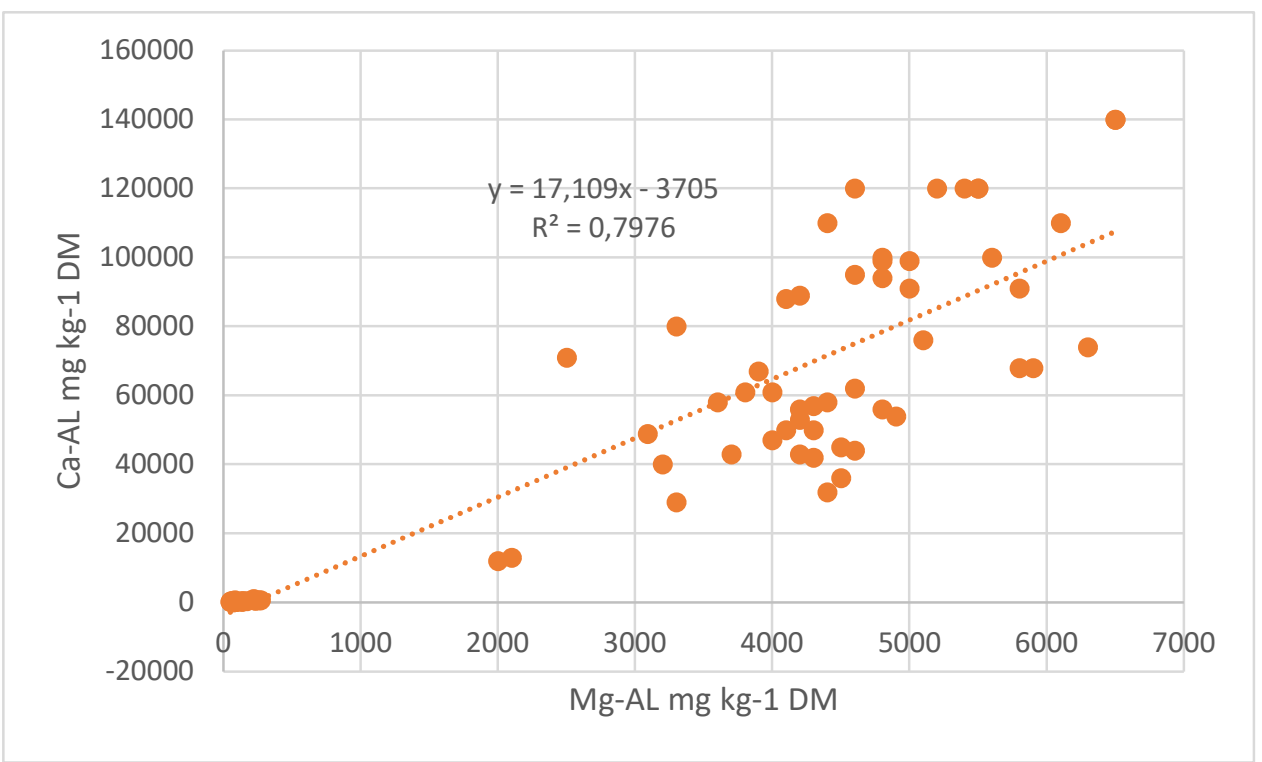

Figure $4 \mathrm{AL}$-extractable Ca vs. AL-extractable Mg for all samples of fishbones, amended with water or $85 \%$ formic acid

Table 4 Average values of AL-extractable $\mathrm{Mg}$ in acidified and water-amended treatments of fine (FFB)

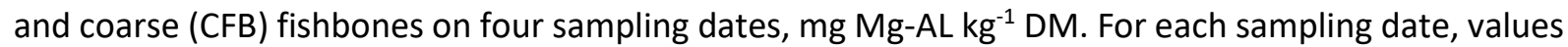
with letters a-d are statistically different at the $5 \%$ level

$\begin{array}{lllll}\text { Treatment } & \text { Day 2 } & \text { Day 15 } & \text { Day 34 } & \text { Day 55 } \\ \text { FFB3 } & 5667 a & 5133 a & 4800 a & 3667 b \\ \text { FFB4 } & 4500 a b & 4333 a & 4433 a & 6000 a \\ \text { CFB3 } & 3567 b c & 5067 a & 5600 a & 4300 a b \\ \text { CFB4 } & 2467 c & 4233 a & 4333 a & 4100 b \\ \text { FFBH2O } & 71 d & 123 b & 112 b & 253 c \\ \text { CFBH2O } & 62 d & 76 b & 101 b & 128 c\end{array}$

Extractable phosphorus in fishbones treated with 85\% formic acid

For phosphorus, the dissolution was much less than for calcium. Surprisingly, extractable P (P-AL) concentrations were much higher in fishbones amended with only water than in fishbones amended with FA to $\mathrm{pH} 4$ (Figure 5). At pH 3, high P-AL concentrations, on average $6.8 \mathrm{~g} \mathrm{P}-\mathrm{AL} \mathrm{kg}^{-1} \mathrm{DM}$, were achieved after 30 days, but only for FFB. For CFB, the P-AL concentration at $\mathrm{pH} 3$ was well below the $\mathrm{P}-\mathrm{AL}$ concentration in water. The P-AL concentration in FFB3 comprised $6 \%$ of the total amount of $\mathrm{P}$ in the fishbones, which on average comprises $115 \mathrm{~g} \mathrm{~kg}^{-1} \mathrm{DM}$ (Table 1).

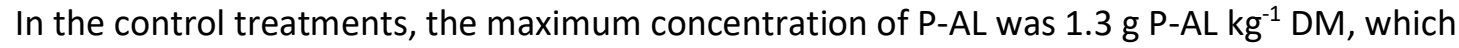
comprises $1.1 \%$ of the total $\mathrm{P}$ content. For fine fishbones, there was a significant decrease over time from 1.3 to $0.6 \mathrm{~g} \mathrm{~kg}^{-1} \mathrm{DM}$ (Figure 3, $\mathrm{FFBH}_{2} \mathrm{O}$ ). This may possibly be explained by microbial activity, changing extractable $\mathrm{P}$ to non-extractable organically bound $\mathrm{P}$.

In acidified treatments, there was a small and nearly significant increase in P-AL from day 2 to 55 in CFB3. For FFB3 and 4, increases from day 2 to 55 were significant, but very small for FFB4. Only for FFB3, the increase was high, and occurred between day 15 and 34 . 


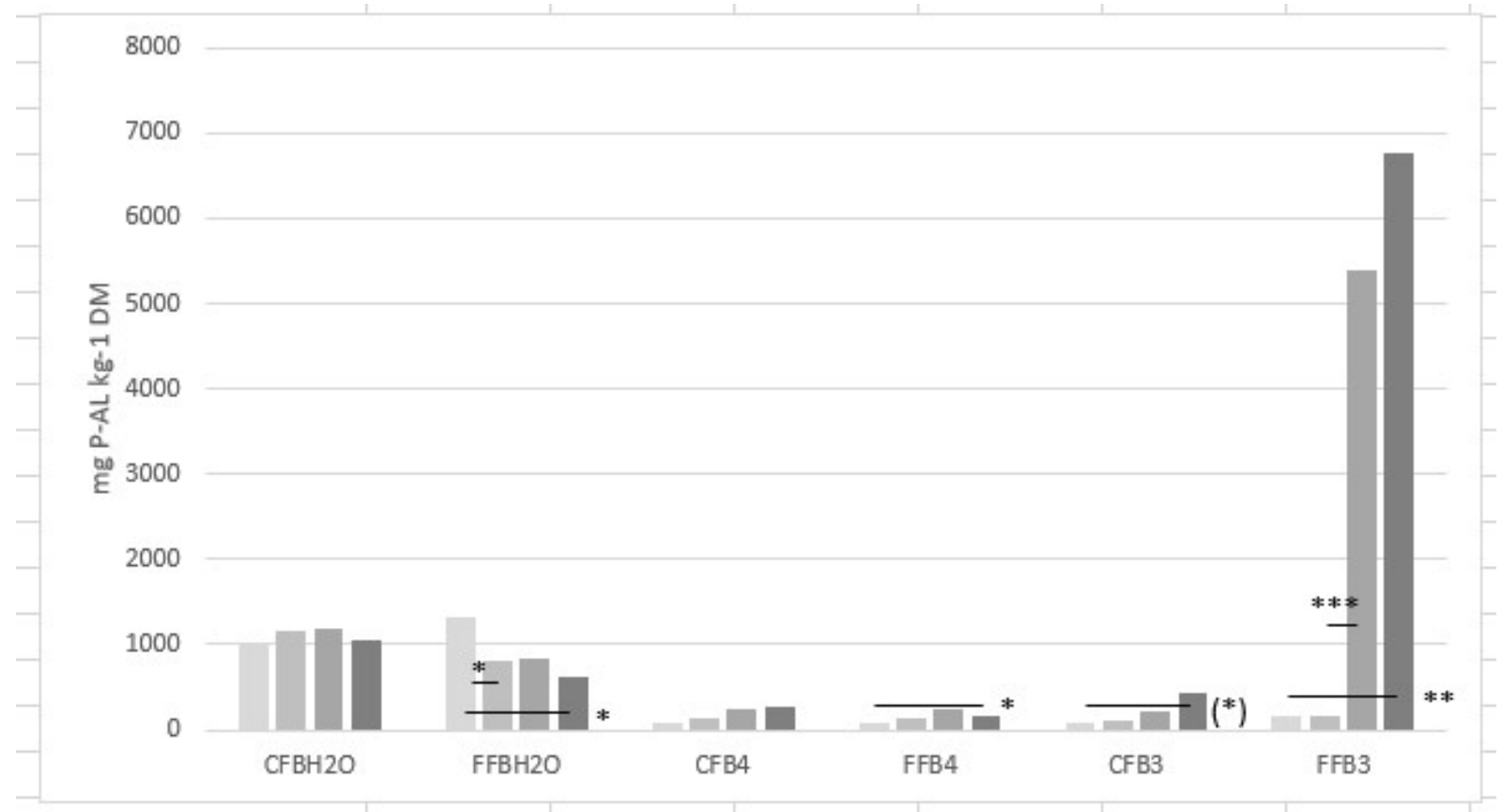

Figure 5 AL-extractable phosphorus (P-AL) at days 2, 15, 34 and 55 after acidification of grinded fishbones with $85 \%$ formic acid to $\mathrm{pH} 3$ or 4 . Values are averages of 3 replicate samples per treatment; sampling days are indicated by increasingly grey colour. CFB= coarse fishbones $(2-4 \mathrm{~mm})$, $\mathrm{FFB}=$ fine fishbones $(<0.71 \mathrm{~mm}), \mathrm{H} 2 \mathrm{O}=$ control with only water, numbers 3 and 4 refer to $\mathrm{pH}$. Statistically significant changes between sampling dates are indicated by horizontal bars between dates and the level of significance by asterix

At each sampling date, the differences between treatments were statistically highly significant $(p=$ 0.000; GLM; Table 5). The control treatments had significantly higher P-AL values than any acidified treatment on day 2 and 15 . On days 34 and 55, a clear and positive effect was found of finely grinding of fishbones at $\mathrm{pH} 3$. Hence, for $\mathrm{P}$ which is possibly the most important nutrient in fishbones from a crop fertilisation perspective, fishbones must be acidified to $\mathrm{pH} 3.0$ for at least 30 days to increase the concentration of AL-extractable P significantly.

Table 5 Average values of AL-extractable P in acidified and water-amended treatments of fine (FFB) and coarse (CFB) fishbones on four sampling dates, $\mathrm{mg} \mathrm{P-AL} \mathrm{kg}{ }^{-1} \mathrm{DM}$. For each sampling date, values with letters $a, b, c$ are statistically different at the $5 \%$ level

$\begin{array}{lllll}\text { Treatment } & \text { Day 2 } & \text { Day 15 } & \text { Day 34 } & \text { Day 55 } \\ \text { FFBH2O } & 1333 a & 813 b & 846 b c & 617 b \\ \text { CFBH2O } & 1017 b & 1167 a & 1200 b & 1063 b \\ \text { FFB3 } & 153 c & 173 c & 5400 a & 6767 a \\ \text { CFB3 } & 85 c & 112 c & 223 c & 420 b \\ \text { FFB4 } & 73 c & 147 c & 243 c & 177 b \\ \text { CFB4 } & 73 c & 127 c & 253 c & 280 b\end{array}$

Extractable potassium in fishbones treated with 85\% formic acid

The average concentrations of extractable potassium (K) were somewhat higher in the control treatments than in acidified slurries and increased over time from 787 to $1023 \mathrm{mg} \mathrm{K} / \mathrm{kg}$ DM for CFB and from 880 to $1023 \mathrm{mg}$ for FFB (Figure 6). In acidified treatments, the K-AL concentrations were 
generally lower for FFB3 than for other treatments and there was no clear pattern of increase over time.

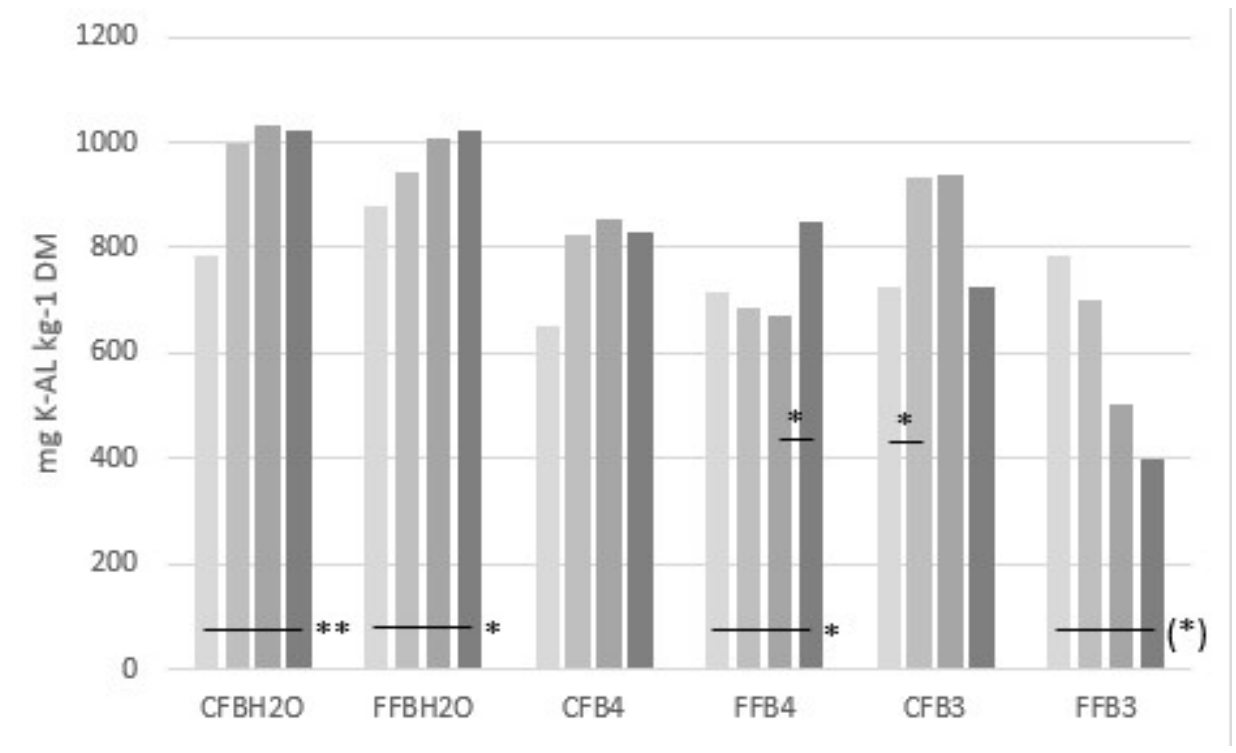

Figure 6 AL-extractable potassium (K-AL) at days 2, 15, 34 and 55 after acidification of grinded fishbones with $85 \%$ formic acid to $\mathrm{pH} 3$ or 4 . Values are averages of 3 replicate samples per treatment; sampling days are indicated by increasingly grey colour. CFB= coarse fishbones $(2-4 \mathrm{~mm})$, $\mathrm{FFB}=$ fine fishbones $(<0.71 \mathrm{~mm}), \mathrm{H} 2 \mathrm{O}=$ control with only water, numbers 3 and 4 refer to $\mathrm{pH}$. Statistically significant changes between sampling dates are indicated by horizontal bars between dates and the level of significance by asterix

\section{Discussion}

\section{$\mathrm{pH}$ increase in control treatments}

The increase of $\mathrm{pH}$ in both control treatments, from about $\mathrm{pH} 7.0$ to 8.0, may be explained by the presence of bacteria which are able to increase the $\mathrm{pH}$ in their environment (Sigurdarson et al. 2018). One possibility may be that urease-producing bacteria were present which were cleaving organic nitrogen into ammonium $\left(\mathrm{NH}_{4}^{+}\right)$. With a starting $\mathrm{pH}$ of about 7.0 , the chemical state would be ammonia $\left(\mathrm{NH}_{3}\right)$. Since the possibility of this gas to emit from the closed plastic bottles was restricted, the production of $\mathrm{NH}_{3}$ in the slurry may have caused an increase in $\mathrm{pH}$.

\section{Formic acid dissolved $\mathrm{Ca}$ and $\mathrm{Mg}$}

The fishbones contained much more $\mathrm{Ca}$ (about $30 \%$ of DM) than $\mathrm{Mg}(0.41-0.57 \%$ of DM, Table 1$)$. The $\mathrm{P}:$ Ca ratio in the fishbones (Table 1 ) indicated that significant calcium carbonate minerals were present, in addition to apatite. For both $\mathrm{Ca}$ and $\mathrm{Mg}$, acidification increased $\mathrm{AL}$-extractable concentrations significantly. This is in line with Braithwaite et al (1996), who found that adding $\mathrm{CaCO}_{3}$ to a substrate of rock $\mathrm{P}$ during extraction of $\mathrm{P}$ with $2 \%$ formic acid significantly affected the solubilisation of $\mathrm{P}$. The proportion of total Ca comprised of Ca-AL was about $30 \%$, whereas for $\mathrm{Mg}$, only about $10 \%$ of the total content was "recovered" as AL-extractable. This indicates that the fishbones likely contained a significant amount of calcite $\left(\mathrm{CaCO}_{3}\right)$ in addition to some dolomite $\left(\mathrm{CaMg}(\mathrm{CO} 3)_{2}\right)$ or possibly even magnesite $\left(\mathrm{MgCO}_{3}\right)$. Several ratios of $\mathrm{Ca}$ to $\mathrm{Mg}$ may be found in 
carbonate minerals. As a geological rule of thumb, calcite dissolves more readily in acidic conditions than minerals containing magnesium (King 2021), which could point to that the fishbone contained significant amounts of calcite. However, the simple analytical procedures applied in the present study are not appropriate for a description of the mineralogy of cod heads.

The dissolved calcium could also be derived from apatite. As reviewed by Boskey and Coleman (2010), carbonate accumulates in the bone cells of animals such as mice, rats and chicken with increasing age. A cod fish may be several years old when being caught; FAO estimates that a typical cod may use about 5 years to reach a size of 30 inches $(76 \mathrm{~cm})$, where the fish may qualify as a cod and not a codling (FAO 2021). Calcium carbonate has been shown to be more readily dissolved at low $\mathrm{pH}$ than hydroxyapatite. In a study of calcium minerals for human intake, Goss et al (2007) reviewed the solubility of various calcium minerals at various $\mathrm{pH}$ from 2.0 to 8.5. At pH 4.5, the observed solubility of calcium phosphate was $0.63 \mathrm{mg} \mathrm{Ca} \mathrm{ml}^{-1}$, whereas the solubility of calcium carbonate at $\mathrm{pH} 4.5$ was 46. This indicates that most of the calcium in carbonates would be dissolved before dissolving of apatite. As discussed in relation to Table 1 , if all $\mathrm{P}$ in the fishbones was present as apatite, about $6 \%$ of the total Ca could be present in carbonates. When about $30 \%$ of the total $\mathrm{Ca}$ is dissolved (as Ca-AL), does this imply that the formic acid has dissolved apatite?

\section{High P-AL in control treatments}

Microbial activity was observed in the control flasks, as evidenced by a yellow colour and strong odour. Microbial activity has been shown to release extractable $P$ from apatite, e.g.by Welch et al. (2002). However, in that study, the $P$ release was explained by acidification. If microbial activity was the reason for the significantly higher concentration of extractable $P$ in the water-amended fishbone slurries, especially at the start of the study, it is reasonable that the concentration would increase over time. Since, on the contrary, a decrease was observed in FFB and the concentration was maintained in CFB, and the concentration was quite high already after two days, the P-AL values seem to reflect that hydrolysed cod head bones contain about $1 \%$ AL-extractable $P$. This P may come from other chemical compounds than apatite. One possibility may be phospholipids, which comprise a significant part of the lipids in the bones of fat fish species. Toppe et al (2007) proposed that a significant fraction of the lipids in bones from lean fish (e.g., cod) is phospholipids.

It is pertinent to ask, why was the concentration of P-AL much lower in fishbones amended with FA to $\mathrm{pH} 4$, than in the control treatments? For coarse fishbones, the P-AL concentrations were also below the levels in the control treatments at $\mathrm{pH}$ 3. Only with finely grinded bones $(<0.7 \mathrm{~mm}), \mathrm{pH} 3.0$ and a contact period of $>30$ days, the P-AL concentrations were significantly increased. One possible explanation for this result is that already at the $1^{\text {st }}$ sampling, significant concentrations of calcium had been dissolved (Figure 2), and were able to react with extractable phosphate ions, precipitating some form of calcium phosphate which was not extractable by the AL solution.

\section{Apatite dissolution and formation of precipitation minerals}

The narrow ratio of liquid to solid material in the slurries most likely supported the precipitation of secondary minerals. Phosphates of both calcium, magnesium and ammonium may have been precipitated, and as discussed above, phosphates from phospholipids may have been precipitated as phosphates not extractable by AL-solution in treatments CFB3, CFB4 and FFB4. If the reason for the significant increase in $\mathrm{P}-\mathrm{AL}$ in $\mathrm{FFB}$ at $\mathrm{pH} 3$ after more than 15 days was that with this $\mathrm{pH}$, degree of milling and storage period apatite was finally weathered, the P-AL increase should have been accompanied by a similar increase in Ca-AL, but that was not the case. Calcium may have become bound to formate anions in the slurries, but such formates are generally highly soluble in aquatic solutions such as the AL-solution. It may be that calcium ions dissolved from apatite after day 15 in 
FFB3 precipitated as calcium carbonate in a form less soluble in AL-solution. Even if the decreases in Ca-AL and Mg-AL from day 34 to 55 were not statistically significant in FFB3, the values indicate that less of these minerals were extractable towards the end of the study. This may possibly be due to some precipitation of little soluble $\mathrm{CaCO}_{3}$ or $\mathrm{CaMg}\left(\mathrm{CO}_{3}\right)_{2}$ after a rapid increase in dissolved $\mathrm{Ca}$ from apatite. Clarification of these processes would demand detailed studies of mineralogy.

\section{More K-AL than total $K$}

In the control treatments, and in FFB4, the concentrations of K-AL increased over time. This may be explained by dissolution of potassium salts, e.g. potassium chloride $(\mathrm{KCl})$. In FFB3, the concentration decreased over time, and the acidified treatments generally had a somewhat lower concentration of K-AL than the controls. The decrease and the lower level I acidified treatments may possibly be explained by formation of some salts containing potassium in the slurries, even if potassium salts are generally highly soluble.

The total content of $\mathrm{K}$ varied from 620 to $750 \mathrm{mg} \mathrm{K} \mathrm{kg}^{-1} \mathrm{DM}$ (Table 1) and comprised on average 685 mg K. Several measurements of K-AL were well above this level, especially in the control treatments. Potassium as a monovalent cation is easily soluble. Hence it is not surprising that a very high proportion of the total $\mathrm{K}$ was extracted by $\mathrm{AL}$ solution in all treatments. It is more difficult to explain why the extractable $\mathrm{K}$ concentrations in the control treatments were well above the total $\mathrm{K}$ values. Potassium comprised a very small proportion of the total mineral content of the fishbones, and it may be that the analytical procedure underestimated this mineral.

\section{Practical application}

For soils in need of maintaining a medium P concentration, e.g. in Norway set to $70 \mathrm{mg}$ P-AL per kg of air-dried soil, a supply of $20 \mathrm{~kg} P$ per hectare and year is applicable (Kristoffersen 2021). To apply 20 $\mathrm{kg}$ of AL-available $\mathrm{P}$ from acidified fishbones, about $2900 \mathrm{~kg}$ per hectare of dry and grinded fishbones would be required. The total application of $\mathrm{P}$ would be about $330 \mathrm{~kg}$, and the application would further apply about $145 \mathrm{~kg} \mathrm{~N}, 20 \mathrm{~kg} \mathrm{~K}, 870 \mathrm{~kg} \mathrm{Ca}, 14 \mathrm{~kg} \mathrm{Mg}, 5 \mathrm{~kg}$ sulphur (S) per hectare. The $\mathrm{N}$ has been shown to have an immediate effect (Ahuja \& Løes 2019), but some source of $K$ would be required to ensure a balanced plant nutrition. For $P$, the residual effect will depend on factors like soil acidity and microbial activity and deserves further study. If not amended with acid, the availability of $\mathrm{P}$ in the fishbones will be much lower, but about $1 \%$ will be readily available. For preservation purpose, the $\mathrm{pH}$ must be 4 or below. One option for practical handling could be to acidify the sediments from 4 to 3 (or below) after the liquid phases of the hydrolysis have been removed. As demonstrated here, a thorough grinding of the bones is required, which may be challenging to conduct with acidified fishbones as the acid will cause corrosion. With the high content of alkali minerals, there should be no risk of soil acidification from applying acidified fishbones to agricultural soil. However, as mentioned the $\mathrm{N}$ availability is very high, which calls for careful timing of the date of application to avoid $\mathrm{N}$ loss.

\section{Conclusions}

This study revealed that a thorough grinding (to particles $<0.7 \mathrm{~mm}$ ) and acidification by application of $85 \%$ formic acid to $\mathrm{pH} 3$ over more than 15 days could dissolve about $6 \%$ of the $\mathrm{P}$ available in bones from cod heads, when assessed in an AL-extraction procedure. With less fine grinding, higher $\mathrm{pH}$ or lower duration of the acidification, AL-extractable $\mathrm{P}$ was decreased by acidification. In fishbones amended with only water, about $1 \%$ of the total $P$ was extracted by AL-solution. Since the 
total content of Pin fishbones is high, about $11.5 \%$ of the dry matter, this is not a neglectable amount. It may be explained by presence of phospholipids.

The AL-soluble concentrations of calcium and magnesium increased significantly by acidification, but there was no large effect of decreasing the $\mathrm{pH}$ from 4 to 3 . Most likely, other minerals than apatite were dissolved by formic acid and later by AL-solution.

Initially, we expected that the concentration of AL-extractable $\mathrm{P}$ in fishbones treated with formic acid would be higher than in fishbones not treated by acid. We also expected that the fineness of grinding, and decrease in $\mathrm{pH}$, would increase the concentration of AL-extractable $\mathrm{P}$ in the fishbones. These assumptions were only partly confirmed. The reason for this is most likely that fishbones contain more minerals than rock phosphate, which affect the dissolution of $\mathrm{P}$.

Further studies will be required to reveal the processes occurring with fishbone minerals during acidification. In practice, for application as fertiliser, it will be more important to measure residual effects of fishbone-derived $\mathrm{P}$ in agricultural soils. Bonemeal from animal husbandry have been extensively studies as soil amendments, whereas much less studies have been carried out for $P$ from fishbones.

\section{Referred literature}

Adeleke, R., Nwangburuka, C., Oboirien, B.: Origins, roles and fate of organic acids in soils: A review. S. Afr. J. Bot. 108, 393-406 (2017.) https://doi.org/10.1016/j.sajb.2016.09.002

Ahuja, I., Løes, A.-K.: Effect of fish bones and algae fibre as fertilisers for ryegrass. NORS $\varnothing \mathrm{K}$ report Vol 4 No 7 2019, Norwegian Centre for Organic Agriculture, Tingvoll, Norway (2019).

https://orgprints.org/id/eprint/36439

Ahuja, I., Dauksas, E., Remme, J.F., Richardsen, R., Løes, A.-K. Fish and fish waste-based fertilizers in organic farming - With status in Norway: A review. Waste Manag. 115, 95-112 (2020).

https://doi.org/10.1016/j.wasman.2020.07.025

Braithwaite, A.C., Eaton, A.C., Groom, P.S.: Some factors associated with the use of the extractants $2 \%$ citric acid and $2 \%$ formic acid as estimators of available phosphorus in fertiliser products. Fertil. Res. 19, 175-181 (1989). https://doi.org/10.1007/BF01054459

Cordell, D., White, S.: Peak Phosphorus: Clarifying the key issues of a vigorous debate about longterm phosphorus security. Sustainability 3(10), 2027-2049 (2011).

https://doi.org/10.3390/su3102027

Dorozkhin, S.V.: Dissolution mechanism of calcium apatites in acids: A review of literature. World Journal of Methodology 2(1), 1-17 (2012). https://www.wjgnet.com/2222-0682/full/v2/i1/1.htm

Égner, H., Riehm, H., Domingo, W.R.: Untersuchungen über die chemische Bodenanalyse als Grundlage für die Beurteilung des Nährtoffzustandes der Boden. II. Chemische Extraktionsmetoden zur Phosphor und Kaliumbestimmung. (Studies of chemical soil analysis to assess the nutrient content of soil. II Chemical extraction methods for measurement of phosphorus and potassium; in German) Kungliga Lantbrukshögskolans Annaler, 26, 199-215 (1960). 
Food and Agriculture Organization of the United Nations (FAO). The Cod.

http://www.fao.org/home/search/en/?q=The\%20Cod\#: :text=www.fao.org-,\%E2\%80\%BA\%20...,The\%20cod\%20is, accessed July 16, 2021

Goss, S.L., Lemons, K.A., Kerstetter, J.E., Bogner, R.H. Determination of calcium salt solubility with changes in $\mathrm{pH}$ and $\mathrm{P}_{\mathrm{CO} 2}$, simulating varying gastrointestinal environments. J Pharm Pharmacology 59, 1485-1492 (2007). https://DOI 10.1211/jpp.59.11.0004

International Fertilizer Industry Association (IFA): Direct application of phosphate rock. https://fertilizer.org//images/Library_Downloads/2013_ifa_direct_application_pr.pdf. Accessed 23 June 2021

Jenza, J.A.: Demystification of organic acid blends. Web post at eFeedLink.com, 5 October 2017. https://www.efeedlink.com/contents/10-05-2017/3a68e442-fbf1-428c-b515-7a77093da9e00101.html. Accesses 21 October 2021

King, H.M.: The "Acid Test" for carbonate minerals and carbonate rocks. https://geology.com/minerals/acid-test.shtml. Accessed 13 October 2021

Kristoffersen, A.: Gjødslingshåndbok (Handbook of fertiliser application; in Norwegian). https://www.nibio.no/tema/jord/gjodslingshandbok?locationfilter=true. Accessed 13 October 2021

Krogstad, T.: Metoder for jordanalyser (in Norwegian: Methods for soil analyses). NHL Institutt for jordfag. Rapport nr 6/92. Norwegian University of Life Sciences, Ås, Norway. (1992).

Løes, A.K., Ahuja, I., deBoer, A. Harvesting our fertilisers from the sea - an approach to close the nutrient gaps in organic farming. Organic World Congress, Rennes, France September 8-10, 2021, Science Forum Topic 4 Innovation in Organic farming. (2021).

Malde, M.K., Bügel, S., Kristensen, M., Malde, K., Graff, I.E., Pedersen, J.I.: Calcium from salmon and cod bone is well absorbed in young healthy men: a double-blinded randomised crossover design. Nutr. Metab. 7 (61), 1-9 (2010). http://www.nutritionandmetabolism.com/content/7/1/61

Porto, G.M., Neto, M.C.A., Finzer, J.R.D.: Solubility of phosphate rocks in citric acid. World Sci. Res. 5(1), 32-36 (2018). https://core.ac.uk/download/pdf/233594435.pdf

Remme, J.F., Carvajal, A.K., Indergård, E., Toldnes, B., Slizyte, R., Grimsmo, L., Austnes, A.: Sluttrapport Heads Up I. Alternativ anvendelse av torskehoder. (In Norwegian: Final report Heads Up I. Alternative applications of cod heads). SINTEF Report 2018: 00475 (2018).

https://www.fhf.no/prosjekter/prosjektbasen/901308/

Sigurdarson, J.J., Svane, S., Karring, H.: The molecular processes of urea hydrolysis in relation to ammonia emissions from agriculture. Rev. Environ. Sci. Bio/Technol. 17, 241-258 (2018). https://doi.org/10.1007/s11157-018-9466-1

Szpak, P.: Fish bone chemistry and ultrastructure: implications for taphonomy and stable isotope analysis. J. Archaeol. Sci. 38, 3358-3372 (2011). https://doi.org/10.1016/j.jas.2011.07.022

Toppe, J., Albrektsen, S., Hope, B., Aksnes, A.: Chemical composition, mineral content and amino acid and lipid profiles in bones from various fish species. Comp. Biochem. Physiol. Part B: Biochem. Mol. Biol. 146 (3), 395-401 (2007). https://doi.org/10.1016/j.cbpb.2006.11.020

Wang, T., Camps-Arbestain, M., Hedley, M., Bishop, P.: Predicting phosphorus bioavailability from high-ash biochars. Plant Soil 357, 173-187 (2012). https://doi.org/10.1007/s11104-012-1131-9 
Welch, S.A., Taunton, A.E., Banfield, J.F. Effect of microorganisms and microbial metabolites on apatite dissolution. Geomicrobio J 19 (3), 343-367 (2002).

https://doi.org/10.1080/01490450290098414 